\title{
Problematyka podstawy prawnej postępowania w sprawie zwrotu dotacji udzielanych z budżetu jed- nostek samorządu terytorialnego
}

The issues of legal basis in proceedings for the repayment of subsidies granted from the budget of local government units

Streszczenie. Punktem wyjścia opracowania jest analiza zmian wprowadzonych ustawą o finansach publicznych z dnia 27 sierpnia 2009 r., która weszła w życie 1 stycznia 2010 r., w odniesieniu do procedury właściwej dla ustalania kwot dotacji podlegających zwrotowi. Autorka zwraca uwagę na pewien paradoks, który daje się zauważyć pod rządami nowej ustawy. Z jednej bowiem strony ustawodawca chciał w sposób systemowy uregulować problematykę finansów publicznych, w tym tę będącą przedmiotem zainteresowania autorki. Z drugiej jednakże strony wywołał wątpliwości w interpretacji przepisów co do trybu rozstrzygania w przedmiocie zwrotu dotacji, których to wątpliwości nie było w okresie obowiązywania poprzedniej ustawy o finansach publicznych z dnia 30 czerwca 2005 r. Dotyczy to zwłaszcza braku delegacji dla organu jednostki samorządu 
terytorialnego do wydania decyzji administracyjnej w przypadku braku zwrotu dotacji w terminie określonym w ustawie. W publikacji przedstawiono zagadnienia stosowania art. 60-67 ustawy o finansach publicznych w kontekście terminów zwrotu dotacji, a także art. 169 ust. 6 tejże ustawy w zestawieniu z treścią art. 252 cyt. ustawy, wskazując na niedostatki regulacji w tym ostatnim przypadku, a to gdy chodzi o tryb postępowania w sytuacji niedokonania zwrotu dotacji w wyznaczonym terminie, która to dotacja została udzielona z budżetu jednostki samorządu terytorialnego. Autorka prezentuje poglądy doktryny i orzecznictwa, wskazując na rozbieżne stanowiska, preferujące bądź to drogę administracyjnoprawną, bądź to drogę cywilnoprawną, a to pomimo upływu znacznego już okresu obowiązywania nowych przepisów. W konkluzji swoich rozważań, autorka opowiada się po stronie zwolenników rozstrzygnięć administracyjnoprawnych dla rozwiązania omawianej problematyki, dostrzegając jednocześnie konieczność określonej korekty komentowanych przepisów przez ustawodawcę.

Słowa kluczowe: zwrot dotacji udzielanych z budżetu jednostek samorządu terytorialnego.

Abstract. The starting point of the paper is the analysis of amendments introduced with the Public Finance Act of 27 August 2009 which entered into force on 1 January 2010 with regard to the procedure applicable for determining the amounts of subsidies subject to repayment. The author points out a certain paradox noticeable under the new legal regime: on the one hand, the legislator intended to regulate in a systemic way the issues of public finance, including those investigated by the author; on the other hand, however, the legislator provoked certain doubts in the construal of the provisions with regard to the mode of adjudication in matters for subsidy repayment, which doubts were absent when the previous Public Finance Act of 30 June 2005 had been in force. This concerns in particular the absence of delegation of powers to a body of the local government unit to issue an administrative decision in case of failure to repay the subsidy within the statutory time limit. The paper discusses the issues of application of Articles 60-67 of the Public Finance Act in the context of time limits for the subsidy repayment, as well as Article 169(6) of the said Act in conjunction with the substance of Article 252 of the said Act, and points out regulatory deficiencies in the latter case, i.e. with regard to the procedural mode when the subsidy is not repaid within the specified time limit, if the subsidy was granted from the budget of a local government unit. The author presents both the theory and the case law, pointing out discrepant opinions which seem to prefer either the path of the ad- 
ministrative law or the path of the civil law, and all of it despite quite a considerable period that lapsed since the entry into force of the new provisions. In conclusion, the author places herself with the supporters of the administrative law adjudications for the solution of the issues in question, admitting however the necessity for the legislator to adjust the discussed provisions appropriately.

Keywords: return of subsidies granted from the budget of local government units.

\section{Wprowadzenie. Procedura właściwa dla ustalania niepodatkowych należności budżetowych po wejściu w życie ustawy o finansach publicznych z dnia 27 sierpnia 2009 r.}

Z dniem wejścia w życie 1 stycznia 2010 r. ustawy o finansach publicznych $^{1}$ (dalej: u.f.p.) obowiązywać zaczęły regulacje dotyczące procedury właściwej dla ustalania niepodatkowych należności budżetowych stanowiących bardzo niejednolitą kategorię należności publicznoprawnych. Zgodnie z art. 60 u.f.p. środkami publicznymi, stanowiącymi niepodatkowe należności budżetowe o charakterze publicznoprawnym, są w szczególności następujące dochody budżetu państwa albo budżetu jednostki samorządu terytorialnego:

- kwoty dotacji podlegające zwrotowi w przypadkach określonych w u.f.p.;

- $\quad$ należności z tytułu gwarancji i poręczeń udzielonych przez Skarb Państwa i jednostki samorządu terytorialnego;

- wpłaty nadwyżek środków obrotowych samorządowych zakładów budżetowych;

- wpłaty nadwyżek środków finansowych agencji wykonawczych;

- $\quad$ wpłaty środków z tytułu rozliczeń realizacji programów przedakcesyjnych;

1 Ustawa z dnia 27 sierpnia 2009 r. o finansach publicznych (tekst jedn. Dz.U. z 2016 r. poz. 1870 ze zm.). 
- należności z tytułu zwrotu środków przeznaczonych na realizację programów finansowanych z udziałem środków europejskich oraz inne należności związane z realizacją projektów finansowanych z udziałem tych środków, a także odsetki od tych środków i od tych należności;

- należności z tytułu grzywien nałożonych w drodze mandatu karnego w postępowaniu w sprawach o wykroczenia oraz w postępowaniu w sprawach o wykroczenia skarbowe;

- dochody pobierane przez państwowe i samorządowe jednostki budżetowe na podstawie odrębnych ustaw;

- $\quad$ pobrane przez jednostkę samorządu terytorialnego dochody związane z realizacją zadań z zakresu administracji rządowej oraz innych zadań zleconych jednostkom samorządu terytorialnego odrębnymi ustawami i nieodprowadzone na rachunek dochodów budżetu państwa.

Wydaje się, że w intencji ustawodawcy przepisy cytowanej ustawy miały mieć charakter systemowy, jednakże już choćby analiza art. 60 i 67 u.f.p. wywołuje zasadnicze wątpliwości. Historycznie rzecz ujmując, w poprzednio obowiązującej ustawie o finansach publicznych z dnia 30 czerwca 2005 r. $^{2}$ tryb rozstrzygania w przedmiocie zwrotu dotacji nie budził wątpliwości poprzez odesłanie do przepisów dotyczących zwrotu dotacji z budżetu państwa (art. 146 ust. 1 w zw. z art. 190 poprzedniej ustawy o finansach publicznych). Tymczasem w obecnej ustawie brak jest delegacji dla organu jednostki samorządu terytorialnego do wydania decyzji administracyjnej w przypadku braku zwrotu dotacji w terminie określonym w ustawie. Problem ten nie doczekał się do chwili obecnej rozstrzygnięcia. Warto więc przybliżyć tę problematykę.

Zgodnie z dyspozycją art. 60 pkt.1 u.f.p. do niepodatkowych należności budżetowych zaliczamy kwoty dotacji podlegające zwrotowi w przypadkach określonych w ustawie. Dotacje stanowią podlegające szczególnym zasadom rozliczania środki z budżetu państwa, budżetu jednostek samorządu terytorialnego oraz z państwowych funduszy celowych przeznaczone na podstawie ustawy o finansach publicznych, odrębnych ustaw lub umów międzynarodowych na finansowanie lub dofinansowanie

2 Ustawa z dnia 30 czerwca 2005 r. o finansach publicznych (Dz.U. Nr 249, poz. 2104 ze zm.). 
realizacji zadań publicznych ${ }^{3}$. Ustawa o finansach publicznych określa tryb i terminy zwrotu dotacji udzielonych z budżetu państwa i budżetów jednostek samorządu terytorialnego oraz wskazuje przesłanki zwrotu dotacji. Dotacje w części niewykorzystanej w terminie, wykorzystanej niezgodnie z przeznaczeniem, pobranej nienależnie lub w nadmiernej wysokości zwracane są do organu, który udzielił dotacji. Zwrotowi w terminie do 31 stycznia następnego roku podlega ta część dotacji, która nie została wykorzystana do końca roku budżetowego ${ }^{4}$. Natomiast kwota dotacji wykorzystana niezgodnie z przeznaczeniem, nienależnie udzielona lub pobrana w nadmiernej wysokości podlega zwrotowi do organu udzielającego dotacji w terminie 15 dni od dnia stwierdzenia nieprawidłowości w jej wykorzystaniu ${ }^{5}$. Przepisy ustawy o finansach publicznych regulujące terminy zwrotu niewykorzystanych dotacji udzielonych z budżetu jednostek samorządu terytorialnego przewidują ponadto dwa szczególne terminy zwrotu niewykorzystanych dotacji. W przypadku zaliczenia niewykorzystanej części dotacji do wydatków niewygasających z upływem roku budżetowego na mocy uchwały organu stanowiącego jednostki samorządu terytorialnego ustalającej wykaz takich wydatków, niewykorzystana cześć dotacji podlega zwrotowi do budżetu jednostki samorządu terytorialnego w terminie 15 dni od terminu określonego w tej uchwale ${ }^{6}$. Drugi szczególny termin zwrotu dotacji udzielonych z budżetu jednostki samorządu terytorialnego związany jest z krótszym niż rok budżetowy terminem wykorzystania dotacji, np. w umowie dotacyjnej zawieranej w przypadku udzielenia dotacji celowej, i wynosi 15 dni od upływu ustalonego terminu wykorzystania dotacji ${ }^{7}$.

Postępowanie w przypadku niedokonania zwrotu dotacji w wyznaczonym terminie udzielonej z budżetu państwa określają przepisy art. 169 ust. 6 u.f.p., zgodnie z którymi organ lub inny dysponent części budżetowej, który udzielił dotacji, wydaje decyzję określającą kwotę zwrotu oraz termin,

\footnotetext{
Art. 126 u.f.p.

Art. 168 ust. 1 i art. 251 ust. 1 u.f.p.

Art. 169 ust. 1 i art. 252 ust. 1 u.f.p.

Art. 251 ust. 2 u.f.p.

Art. 251 ust. 3 i art. 252 ust. 2 u.f.p.
} 
od którego nalicza się odsetki. Z kolei, jak już wyżej wspomniano, art. 252 u.f.p. dotyczący zwrotu dotacji udzielonych z budżetu jednostki samorządu terytorialnego nie zawiera delegacji dla organu jednostki samorządu terytorialnego do wydania decyzji administracyjnej w przypadku, gdy zwrot dotacji nie zostanie dokonany w wyznaczonym terminie. Tryb postępowania w przypadku niedokonania w terminie zwrotu dotacji do budżetu jednostki samorządu terytorialnego nie jest więc określony w ustawie o finansach publicznych expressis verbis, co stało się przyczyną rozbieżności w orzecznictwie czy w omawianym przypadku właściwe jest dochodzenie zwrotu dotacji przed sądem cywilnym, czy też właściwy jest tryb administracyjny i czy istnieją jednoznaczne podstawy do wydania decyzji administracyjnej w tej sprawie. Dla przykładu udzielenie dotacji z budżetu jednostki samorządu terytorialnego na podstawie ustawy odrębnej, jaką jest ustawa o działalności pożytku publicznego i wolontariacie ${ }^{8}$, następuje przez zawarcie umowy o wsparcie lub powierzenie realizacji zadania publicznego ${ }^{9}$, co wprowadza do procedury o udzielenie dotacji element cywilnoprawny, mogący wskazywać na możliwość ubiegania się o jej zwrot na drodze przepisów Kodeksu cywilnego, dotyczących odstąpienia od umowy lub roszczeń przewidzianych w przypadku niewykonania lub nienależytego wykonania zobowiązania. Jednakże przypadek ten należy traktować raczej jako wyjątek, a nie regułę. Problematyka ta jest tym bardziej aktualna, jeśli zważyć na fakt coraz intensywniejszego zacierania się granic pomiędzy prawem publicznym i prywatnym i swoistym wypieraniem prawa administracyjnego przez prawo prywatne, na co zwrócił uwagę Pierwszy Prezes Sądu Najwyższego w swoim przemówieniu okolicznościowym z okazji Zgromadzenia Ogólnego Sędziów NSA 22 kwietnia 2015 r., odnosząc te uwagi zwłaszcza do prawa dotacyjnego ${ }^{10}$.

8 Ustawa z dnia 24 kwietnia 2003 r. o działalności pożytku publicznego i o wolontariacie (Dz.U. z 2016 r., poz. 1817).

Art. 16 ust. 1 ustawy o działalności pożytku publicznego i o wolontariacie.

10 Przemówienie okolicznościowe Pierwszego Prezesa SN na Zgromadzeniu Ogólnym Sędziów NSA 22 kwietnia 2015 r. - publikowane na stronie www.nsa.gov.pl 


\section{Kontrowersje wokół podstawy prawnej do wydania decyzji nakazującej zwrot dotacji w orzecznictwie sądów administracyjnych oraz doktrynie}

Problem podstawy prawnej do wydania decyzji nakazującej zwrot dotacji znalazł swoje odbicie w orzecznictwie sądów administracyjnych, które wskazywały, choć nie zawsze, na tryb administracyjny jako właściwy w przypadku zwrotu dotacji udzielonych z budżetu jednostek samorządu terytorialnego. Co więcej, można odnieść wrażenie, że wobec niedostatków regulacji ustawowej sądy stanęły przed swoistą koniecznością rozstrzygnięcia omawianej problematyki. Wykładni systemowej prawa w omawianym zakresie, z uwzględnieniem dotychczasowego dorobku doktryny, dokonał Wojewódzki Sąd Administracyjny w Białymstoku w wyroku z dnia 2 kwietnia 2014 r. W wyroku tym sąd przyjął, iż mając na uwadze treść art. 252 w związku z art. 61 i 60 u.f.p. oraz fakt, że podstawową formą załatwienia sprawy administracyjnej jest decyzja administracyjna, uznać należy, że określenie zwrotu dotacji na rzecz budżetu jednostek samorządu terytorialnego następuje w drodze decyzji deklaratoryjnej, a przesłanką jej wydania jest stwierdzenie, iż dotacja została wykorzystana niezgodnie z przeznaczeniem lub została pobrana nienależnie lub w nadmiernej wysokości ${ }^{11}$. W istocie więc WSA w Białymstoku w sposób jednoznaczny podzielił pogląd zarówno orzecznictwa NSA, jak i doktryny, zgodnie z którym w przypadkach, gdy ustawodawca, nie wskazując wyraźnie formy prawnej działania, upoważnił organ administracji do rozstrzygnięcia indywidualnej sprawy jednostki, kierować należy się tzw. domniemaniem rozstrzygnięcia sprawy w formie decyzji administracyjnej. Pogląd ten rozwinięty został szczegółowo w uchwale NSA z dnia 24 maja 2012 r. ${ }^{12}$

11 Wyrok WSA w Białymstoku z dnia 2 kwietnia 2014 r., I SA/Bk 634/13, CBOSA.

12 Uchwała NSA z dnia 24 maja 2012 r., II GPS 1/12, ONSAiWSA z 2012 r., nr 4, poz. 62; wyrok WSA w Białymstoku z dnia 2 kwietnia 2014 r., I SA/Bk 634/13, CBOSA; por. także R. Mazur [w:] M. Korolewska, A. Babczuk (red.), Dotacje z budżetu jednostek samorzqdu terytorialnego - stan obecny i kierunki pożq̨danych zmian. Konferencja: Warszawa, 23 czerwca 2014 r., Warszawa 2014, s. 23; por. także B. Adamiak, 
Zarówno NSA, jak i WSA w Białymstoku odwołują się w tym kontekście do tezy wyrażonej w wyroku TK z 14 czerwca 2006 r., w myśl której zgodnie z zasadą demokratycznego państwa prawnego wszelkie postępowania prowadzone przez organy władzy publicznej w celu rozstrzygnięcia spraw indywidualnych odpowiadać powinny standardom sprawiedliwości proceduralnej $^{13}$. Teza ta niejako nawiązuje do wyroku NSA z dnia 23 lutego 2005 r., gdzie sąd ten stwierdza, iż prawo do procesu, którego źródłem jest konstytucyjna zasada demokratycznego państwa prawnego, „(...) ma podstawowe znaczenie dla interpretacji przepisów prawa materialnego w kwestii formy rozstrzygnięcia sprawy, w kierunku przyjęcia zasady załatwiania spraw jednostki w formie decyzji administracyjnej, gdy przepis prawa materialnego nie przyjmuje expressis verbis innej formy załatwienia sprawy." 14 W konkluzji swojego wyroku WSA w Białymstoku stwierdził, że w przypadku, gdy przepisy prawa materialnego administracyjnego przewidują kompetencje określonego organu do załatwienia sprawy jednostki w formie aktu indywidualnego przy jednoczesnym braku wyraźnego przepisu przewidującego odmienną formę załatwienia sprawy, winno to nastąpić w drodze decyzji ${ }^{15}$. Uprzednio podobne stanowisko można odnaleźć chociażby w wyroku WSA w Opolu z dnia 15 września 2010 r., zgodnie z którym nie sposób zakwestionować, iż mamy do czynienia w omawianych przypadkach z postępowaniem administracyjnym, a od kończącej to postępowanie decyzji przysługuje, zgodnie z art. 3 § 2 pkt 1 ustawy z dnia 30 sierpnia 2002 r. Prawo o postę-

J. Borkowski, Kodeks postępowania administracyjnego. Komentarz, Wydanie 6, Wydawnictwo C.H. Beck, Warszawa 2004 r., s. 455; A. Skoczylas, System Prawa Administracyjnego. Tom 9. Prawo procesowe administracyjne, Warszawa 2010, s. 94; M. Dyl [w:] M. Wierzbowski, A. Wiktorowska (red.), Kodeks postępowania administracyjnego. Komentarz, Warszawa 2011, s. 524. Na konieczność wydania decyzji administracyjnej wskazuje m. in. K. Sawicka, Wydatki w formie dotacji z budżetu jednostki samorzqdu terytorialnego [w:] A. Pomorska, P. Smoleń, J. Stelmasiak, A. Gorgol (red.), Prawo finansowe w warunkach członkostwa Polski w Unii Europejskiej. Księga Jubileuszowa dedykowana Profesor Wandzie Wójtowicz, Lublin 2011, s. 416. Wyrok TK z dnia 14 czerwca 2006 r., K 53/05, Dz.U. 2006, nr 118, poz. 812 Wyrok NSA z dnia 23 lutego 2005 r., OSK 1185/04, LEX nr 165713. Wyrok WSA w Białymstoku z dnia 2 kwietnia 2014 r., I SA/Bk 634/13, CBOSA. Analogicznie: M. Dyl [w:] M. Wierzbowski, A. Wiktorowska (red.), Kodeks postępowania administracyjnego. Komentarz, Warszawa 2011, s. 524. 
powaniu przed sądami administracyjnymi ${ }^{16}$ skarga do sądu administracyjnego. Zatem nieuprawnionym i niemającym żadnego oparcia w przepisach regulujących postępowanie dotyczące zwrotu dotacji ze środków publicznych jest twierdzenie o cywilistycznym charakterze sporu o zwrot dotacji i o kompetencji sądu powszechnego do rozstrzygania tej kwestii ${ }^{17}$. Odmienne stanowisko zajął WSA w Olsztynie w wyroku z 23 listopada 2011 r., w którym stwierdził, że kwestia trybu rozstrzygania w przedmiocie zwrotu dotacji udzielanych przez organ j.s.t. stała się wątpliwa po wejściu w życie u.f.p. z 27 sierpnia 2009 r. W ocenie sądu nieuzasadnionym jest sięganie w tym zakresie do art. 61 tejże ustawy, ponieważ reguluje on właściwość organów rządowych i samorządowych w sprawach umorzenia obowiązku zwrotu dotacji i kwestie decyzji o pobraniu zwrotu dotacji w drodze potrącenia z należności j. s. t. na rzecz zobowiązanego. W tych warunkach, zdaniem Sądu, można rozważyć stosowanie drogi cywilnoprawnej w oparciu o przepisy dotyczące bezpodstawnego wzbogacenia lub zwrotu świadczenia niż drogi administracyjnoprawnej, zakładającej możliwość wydania decyzji określającej kwotę zwrotu dotacji ${ }^{18}$.

Z tego krótkiego przeglądu orzecznictwa wynika, iż uprawnionym pozostaje twierdzenie, że uregulowania obecnie obowiązującej ustawy z dnia 27 sierpnia 2009 r. o finansach publicznych nie dają precyzyjnej odpowiedzi na pytanie, w jaki sposób organ udzielający dotacji powinien dochodzić jej zwrotu w sytuacjach określonych w tej ustawie, a więc $\mathrm{w}$ razie wykorzystania dotacji niezgodnie z przeznaczeniem, pobrania dotacji nienależnie lub w nadmiernej wysokości. Sytuacja w tym zakresie, jak wspomniano, była inna przed wejściem w życie tej ustawy, a więc przed 1 stycznia 2010 r., bowiem wcześniej z treści art. 190 w zw. z art. 145 i art. 146 ust. 1 ustawy z dnia 30 czerwca 2005 r. o finansach publicznych wynikało, że w sprawie zwrotu dotacji wydawana jest decyzja administracyjna przez wójta (burmistrza, prezydenta miasta), starostę lub marszałka województwa, a organem odwoławczym jest samorządowe kole-

16 Tekst jedn. Dz.U. z 2016 r., poz. 718 ze zm.

17 Wyrok WSA w Opolu z dnia 15 września 2010 r., I SA/Op 454/10, CBOSA; podobnie: wyrok WSA w Poznaniu z dnia 25 września 2012 r., I SA/Po 410/12, CBOSA.

18 Wyrok WSA w Olsztynie z dnia 23 listopada 2011 r., I SA/Ol 663/11, CBOSA. 
gium odwoławcze. W art. 252 obecnie obowiązującej ustawy z dnia 27 sierpnia 2009 r. o finansach publicznych ustawodawca zdefiniował jedynie pojęcie dotacji udzielonych z budżetu jednostki samorządu terytorialnego, pobranych nienależnie lub w nadmiernej wysokości, określił terminy zwrotu tych dotacji oraz dotacji wykorzystanych niezgodnie z przeznaczeniem, sposób obliczania części dotacji podlegającej zwrotowi oraz naliczanie odsetek od tej części. Można więc postawić zasadne pytanie, czy brak ten jest efektem zaniedbań regulatora, czy też zabiegiem celowym. Interesującą odpowiedź przedstawił W. Lachiewicz, według którego w pracach legislacyjnych nad ustawą, prowadzonych w latach 2008-2009, wskutek pewnego niezrozumienia sensu nowych uregulowań wycięto z jej treści przepis o decyzjach administracyjnych przewidujących zwrot dotacji do budżetu samorządu ${ }^{19}$.

W piśmiennictwie można spotkać się z poglądem, zgodnie z którym podstawę prawną do wydania decyzji administracyjnej o zwrocie dotacji

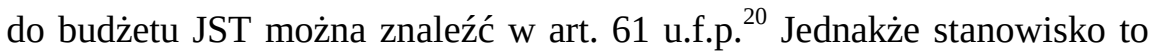
wydaje się być kontrowersyjne. Wypada podzielić pogląd, że literalna treść tego przepisu dowodzi, iż ustawodawca zawarł w nim jedynie normę o właściwości organów, nie zaś normę kompetencyjną ${ }^{21}$. Interesujące stanowisko zajął w komentowanej problematyce WSA w Łodzi w postanowieniu z dnia 1 sierpnia 2012 r., zgodnie z którym „(...) należy jednak rozważyć, czy mimo braku jednoznacznie brzmiącego przepisu przewidu-

19 W. Lachiewicz [w:] M. Korolewska, A. Babczuk (red.), Dotacje z budżetu jednostek samorzq̨du terytorialnego - stan obecny i kierunki pożqdanych zmian. Konferencja: Warszawa, 23 czerwca 2014 r., Warszawa 2014, s. 29.

20 D. Drozdowski, P. Ciszewski [w:] A. Walasik, A. Babczuk, A. Talik (red.), Dotacje z budżetów jednostek samorzq̨u terytorialnego, Warszawa 2013, s. 32 i n.

21 W. Lachiewicz [w:] W. Lachiewicz (red.), Finanse publiczne. Praktyka stosowania nowej ustawy o finansach publicznych i aktów wykonawczych, Warszawa 2010, s. 444-445. W zakresie dotacji z budżetu państwa patrz: W. Miemiec, K. Sawicka, M. Miemiec, Prawo finansów publicznych sektora samorzq̨dowego, Warszawa 2013, s. 126-127 oraz Z. Ofiarski, Prawo finansowe, Warszawa 2007, s. 201-205. Por. także: J. Gliniecka, Subwencje i dotacje jako dochody zasilajq̨ce budżety jednostek samorzq̨du terytorialnego, „Gdańskie Studia Prawnicze” 2005, nr 14, s. 623-626. Odnośnie dotacji z budżetów samorządów patrz: W. Lachiewicz, M. Legutko, M. Winiarz (red.), Udzielanie dotacji z budżetów samorzq̨dów ze wzorami dokumentów, komentarzem i orzecznictwem, Warszawa 2006, s. 20-29. 
jącego obowiązek wydania przez określony organ decyzji administracyjnej określającej kwotę zwrotu dotacji możliwość taka istnieje.”22

W ocenie sądu brak wyraźnego odesłania na drogę cywilnoprawną w zakresie dochodzenia zwrotu dotacji może oznaczać, że podmiot wymieniony w art. 61 u.f.p., określającym właściwość organów do wydania decyzji, ma prawo i obowiązek wydać decyzję o zwrocie dotacji. Na podstawie art. 60 pkt. 1 i art. 61 u.f.p. wywodzić można bowiem, że intencją ustawodawcy było to, aby organ wymieniony w art. 61 u.f.p. wydał decyzję o zwrocie takiej dotacji, która zwrotowi podlega, za wyjątkiem sytuacji uregulowanych w odrębnych przepisach (art. 220 u.f.p.) lub w innych ustawach $^{23}$.

Wbrew pozorom zajęciu jednoznacznego stanowiska nie pomaga treść art. 67 u.f.p., który to przepis, w odniesieniu do postępowania w sprawach dotyczących należności, o których mowa w art. 60 tejże ustawy, odsyła do regulacji ustawy z 14 czerwca 1960 r. - Kodeks postępowania administracyjnego ${ }^{24}$, które mają być stosowane wprost, a w zakresie kwestii materialnoprawnych odsyła do przepisów działu III Ordynacji podatkowej ${ }^{25}$, które mają być stosowane odpowiednio. Na aprobatę zasługuje pogląd, zgodnie z którym o ile konieczność stosowania przepisów kodeksu postępowania administracyjnego i Ordynacji podatkowej w sprawach w ogóle nieuregulowanych przepisami u.f.p. jest oczywista, o tyle w sprawach poddanych jej regulacji zawsze może pojawić się pytanie, czy chodzi o unormowanie wyczerpujące i czy dopuszczalne jest stosowanie uzupełniające przepisów Ordynacji ${ }^{26}$.

Opisane wątpliwości uzasadniają postulat uzupełnienia przepisów art. 251-253 u.f.p. o przepis zawierający wyraźną podstawę do wydania decyzji administracyjnej w przedmiocie zwrotu dotacji. Decyzja taka po-

\footnotetext{
22 Postanowienie WSA w Łodzi z dnia 1 sierpnia 2012 r., I SA/Łd 742/12, LEX nr 1265764.

23 Tamże.

24 Ustawa z dnia 14 czerwca 1960 r. Kodeks postępowania administracyjnego (tekst jedn. Dz.U. z 2016 r., poz. 23 ze zm.).

25 Ustawa z dnia 29 sierpnia 1997 r. Ordynacja podatkowa (tekst jedn. Dz.U. z 2017 r., poz. 201).

26 M. Bitner, [w:] W. Misiąg, A. Nowak-Far, Ustawa o finansach publicznych. Komentarz, Warszawa 2015, s. 273.
} 
winna wywodzić się - jeśli chodzi o jej sentencję - nie z przepisu, że organ wydaje decyzję, bo jest do tego właściwy, ale z przepisu, który określi sentencję. Tym samym możliwe byłoby zawarcie postulowanego przepisu np. w postaci art. 253a czy też art. 252a, który mógłby zawierać wszystkie zagadnienia $^{27}$.

Jednakże najbardziej właściwym wydaje się rozwiązanie najprostsze, a mianowicie wprowadzenie przy okazji kolejnej noweli u.f.p. analogicznego uregulowania do art. 169 ust. 6 tej ustawy, co pozwoliłoby uniknąć dotychczasowych kontrowersji i sporów.

\section{Podsumowanie}

Tytułem reasumpcji zasygnalizowanych problemów należy rozważyć, czy brak wyraźnego odesłania na drogę postępowania przed sądem powszechnym w zakresie dochodzenia zwrotu dotacji nie oznacza, że podmiot wymieniony w art. 61 u.f.p. ma prawo i obowiązek wydać decyzję o zwrocie dotacji. Jakkolwiek przepis ten określa jedynie właściwość organów do wydania decyzji, to jednocześnie na podstawie art. 60 pkt 1 i art. 61 tej ustawy można wywodzić, że intencją ustawodawcy było to, aby wymieniony w przepisie organ wydawał decyzję o zwrocie takiej dotacji, która zwrotowi podlega, za wyjątkiem sytuacji uregulowanych w odrębnych przepisach (art. 220 u.f.p.) lub w innych ustawach. Taka jest linia orzecznictwa i praktyki.

Nie zmienia to faktu, że w charakterze postulatu de lege ferenda należałoby oczekiwać od ustawodawcy jednoznacznego uregulowania tej kwestii w u.f.p., analogicznie jak to ma miejsce w odniesieniu do zwrotu dotacji z budżetu państwa.

27 W. Lachiewicz, [w:] M. Korolewska, A. Babczuk (red.), Dotacje z budżetu jednostek samorzqdu terytorialnego - stan obecny i kierunki pożqdanych zmian. Konferencja: Warszawa, 23 czerwca 2014 r., Warszawa 2014, s. 29. Analogicznie: R. Mazur, [w:] M. Korolewska, A. Babczuk, Dotacje..., s. 27. 
Problematyka podstawy prawnej postępowania....

\section{Bibliografia:}

Adamiak B., Borkowski J., Kodeks postępowania administracyjnego. Komentarz, Wydawnictwo C.H. Beck, Warszawa 2004.

Gliniecka J., Subwencje i dotacje jako dochody zasilające budżety jednostek samorzq̨du terytorialnego, „Gdańskie Studia Prawnicze” 2005, nr 14, s. 617-626.

Lachiewicz W. (red.), Finanse publiczne. Praktyka stosowania nowej ustawy o finansach publicznych i aktów wykonawczych, Wydawnictwo C.H. Beck, Warszawa 2010.

Lachiewicz W. [w:] M. Korolewska, A. Babczuk (red.), Dotacje z budżetu jednostek samorzqdu terytorialnego - stan obecny i kierunki pożądanych zmian. Konferencja: Warszawa, 23 czerwca 2014 r., Wydawnictwo Sejmowe, Warszawa 2014.

Lachiewicz W., Legutko M., Winiarz M. (red.), Udzielanie dotacji z budżetów samorzq̨ów ze wzorami dokumentów, komentarzem i orzecznictwem, MUNICIPIUM SA, Warszawa 2006.

Mazur R. [w:] M. Korolewska, A. Babczuk (red.), Dotacje z budżetu jednostek samorzqdu terytorialnego - stan obecny i kierunki pożq̨danych zmian. Konferencja: Warszawa, 23 czerwca 2014 r., Wydawnictwo Sejmowe, Warszawa 2014.

Miemiec W., Sawicka K., Miemiec M., Prawo finansów publicznych sektora samorzqdowego, Wolters Kluwer Polska S.A., Warszawa 2013.

Misiąg W., Nowak-Far A., Ustawa o finansach publicznych. Komentarz, Wydawnictwo C.H. Beck, Warszawa 2015.

Ofiarski Z., Prawo finansowe, Wydawnictwo C.H. Beck, Warszawa 2007.

Sawicka K., Wydatki w formie dotacji z budżetu jednostki samorzqdu terytorialnego [w:] A. Pomorska, P. Smoleń, J. Stelmasiak, A. Gorgol (red.), Prawo finansowe $w$ warunkach członkostwa Polski w Unii Europejskiej. Księga Jubileuszowa dedykowana Profesor Wandzie Wójtowicz, Lublin 2011, s. 407-417.

Skoczylas A., System Prawa Administracyjnego. Tom 9, Prawo procesowe administracyjne, Wydawnictwo C.H. Beck, Warszawa 2010.

Walasik A., Babczuk A., Talik A. (red.), Dotacje z budżetów jednostek samorzqdu terytorialnego, Wydawnictwo C.H. Beck, Warszawa 2013.

Wierzbowski M., Wiktorowska A. (red.), Kodeks postępowania administracyjnego. Komentarz, Wydawnictwo C.H. Beck, Warszawa 2011. 